Para enlazar con este artículo / To link to this article:

http://dx.doi.org/10.6035/MonTI.2018.10.6

Para citar este artículo / To cite this article:

Canepari, Michela. (2018) "Using audiovisual material in teaching medical translation to non-medical students." In: Montalt, Vicent; Karen Zethsen \& Wioleta Karwacka (eds.) 2018. Retos actuales y tendencias emergentes en traducción médica / Current challenges and emerging trends in medical translation. MonTI 10, pp. 141-176.

\title{
USING AUDIOVISUAL MATERIAL IN TEACHING MEDICAL TRANSLATION TO NON-MEDICAL STUDENTS
}

\author{
Michela Canepari \\ University of Parma \\ michela.canepari@unipr.it
}

\begin{abstract}
This paper aims at exploring new methodologies to make the practice of medical translation more interesting and stimulating for language students. It is based on two third year courses held at the University of Parma (Italy), for undergraduates reading modern languages. The courses made great use of audio-visual materials, which translate intersemiotically and often, intralinguistically, the language used in specialized domains. The original and dubbed versions of some of the most popular television series whose focus is, precisely, the language of medicine (namely House M.D. and Scrubs) were the basis for a series of activities aimed at helping students approach the study of medical translation for the first time.
\end{abstract}

\section{Sinossi}

Larticolo mira a esplorare nuove metodologie atte a rendere l'approccio allo studio della traduzione medica stimolante e originale ed è basato su due corsi di terzo anno tenuti all'Università di Parma (Italia), per studenti del Corso in Lingue e Civiltà Straniere Moderne. Durante i corsi si è fatto largo uso di materiali audiovisivi che traducono intersemioticamente e, spesso, intralinguisticamente, il linguaggio medico utilizzato in ambito specialistico. Le versioni originali e doppiate di alcune serie televisive incentrate sul linguaggio medico (nello specifico Dr. House M.D. e Scrubs), hanno dunque costituito la base per una serie di attività mirate a facilitare l'avvicinamento degli studenti allo studio della traduzione medica.

Keywords: English for Medical Purposes. Medical translation. Intersemiotic translation. Audiovisual translation. Didactic aspects of medical translation. 
Parole chiave: Inglese medico. Traduzione medica. Traduzione intersemiotica. Traduzione audiovisiva. Aspetti didattici della traduzione medica. 


\section{Introduction: a "humanistic" approach to specialized translation}

In our globalized world, where societies are shaped by important migratory flows, issues of translation have become more and more pivotal. In particular, the field of specialized translation has increasingly acquired greater importance. On the one hand, in fact, English is often considered the main lingua franca of specialized communication (particularly in the medical field, since most of medical books and journals are written in English). On the other, in our societies migrants need, on a regular basis, translation services for both legal and medical purposes among others. Indeed, although specialized languages were born as the expression of particular groups of professionals in specific areas of study, and their translation was therefore mainly directed to other specialists, in our contemporary world speakers often come across and need specialized languages in their daily lives too.

As a consequence, very often, the practice of specialized translation posits itself at an intersection where two different areas of translation theory overlap. On the one hand, translators are in fact required to translate interlinguistically (Jakobson 1959) the language of medicine, with all its peculiar lexical and morphosyntactic features; on the other, they often have to translate intralinguistically (Jakobson 1959) that same language, in order to make it more comprehensible for all the people involved in communicative exchanges. And this holds true both when the translations required involve written texts, and when they rely on spoken language, that is to say when simultaneous and/or sequential interpretations become necessary, for example in hospitals, counselling centres and so on.

As discussed in detail elsewhere (Canepari 2013; 2017 \& forthcoming), this aspect is in actual fact at the very core of the process of popularization that has become increasingly important in our contemporary world, and it is indubitable that the new media have contributed enormously to this practice. Indeed, the intralinguistic translations provided by popular programs of various kinds (from television series to documentaries) - together with other products available on the internet - lay emphasis on various aspects. On the one hand, these programs and products can make the public aware of some of 
the linguistic features that specialized languages take in their various national forms, since most of these products are translated audio-visually in order to be exported to various countries. As a result, within the field of medicine, viewers are often confronted with acronyms, compounds, words of classical origin etc., typical of medical language. On the other hand, these products implicitly address the various social, cultural and philosophical issues which are closely connected to the notion of a wider sharing of information and the implementation of more democratic forms of knowledge which, in turn, could help subjects achieve greater control over their lives, both within and, in the case of migrants, outside their national borders.

The interest in Language for Specific Purposes and their translation cannot therefore be conceived simply as a stimulating academic field of analysis, but also - and more importantly - as an increasing necessity which has many practical repercussions. In this sense, the teaching of specialized translation is acquiring greater importance and should be aimed at the formation of professional figures able to rise to the challenges of contemporary society, and at the education of citizens of a world which is both progressively specialized and increasingly intercultural. Thus, also within specialized domains, the notion of cultural mediation becomes paramount and should integrate the different levels of culture originally identified by Hall (1959) and later re-elaborated by Brake et al. (1995) among others: from the specialist and technical to the invisible ones.

This is the reason why, in recent years, even the focus of medical education per se has shifted considerably, leading to the birth of the inter- and multidisciplinary field we refer to as Medical Humanities, where the arts, the social sciences and the humanities proper intersect. The main aim of this field is notably to offer all the subjects involved in the medical process the necessary tools to understand both disease and health, placing these conditions in a social and cultural context. In the attempt to favour a greater empathic understanding of the Subject him/herself, of the Other and of the therapeutic process, Medical Humanities therefore encourages professionals to explore cultural notions of health and illness; the physical, psychological and emotional impact illness can have on both the patients and the people around them; the metaphors which different cultures exploit to describe the illness and the therapy it involves, etc.

The kind of translator Medical Humanities calls for, therefore corresponds to a new figure, one that might bring together the specialization required by the field with the willingness to approach the patients, their families and their loved ones, not only as patients but as whole human beings. Indeed, in order to counteract the objectification and otherization of patients enacted by medicine 
during the course of centuries through the "medical gaze" of doctors and their language (Foucault $1961 \&$ 1963), Medical Humanities attempts to turn the patient, once again, into a Subject (see for instance: Bleakley 2015). Naturally, since an accurate and effective communication is essential and, within the field of medicine, absolutely necessary to safeguard the patients' safety (Hull 2015), language proficiency and precision for both professionals and translators/interpreters is inevitable. However, as Sanchéz-Reyes maintains, there is a need for an "ongoing revision of methodological approaches in the ESP context" (2011: 231). This, naturally, in order to form better medical staff but also, as it is my contention here, to form all those professionals who are not directly involved in a medical profession, but whose aid is often essential in medical contexts, namely specialized translators.

Indeed, it is true that the features of monorefentiality and absence of ambiguity typical of specialized languages (see Gotti 2005) often enable translators to opt for an adequate lexical equivalent. Yet, according to the situational context and to the participants in the communicative act, other strategies might become necessary, in order for translators to act as cultural mediators whose work is informed not only by technical knowledge but also by cultural awareness. After all, as Newmark (1988: 151) maintains,

technical translation is primarily distinguished from other forms of translation by terminology, although terminology usually only makes up about $5-10 \%$ of a text.

In actual fact, within the field of specialized languages in general, the focus on terminology has long since been recognized as only one of the many skills translators and interpreters need to possess. And this appears particularly true in a field such as medicine, where issues of life and death, pain and suffering are often at the centre of many communicative exchanges between doctors and patients. The idea that the translator should always be ready to put him/herself in the place of the Other, together with the many social, cultural and ethical issues raised by the television series under study (the homeless, alcoholism, drug addiction, single parenting, euthanasia and so on) thus help students reflect on some of these aspects, which often appear paramount in our societies too. In actual fact, the research conducted by Mureşean et el. equally suggested that introducing controversial topics in the EMP class is highly beneficial, in that it gives students the possibility to develop their medical English language skills, their oral and written communication abilities, and their critical thinking skills (Mureşan et al. 2016: 172), while encouraging their reflection on the way different cultures may approach some of these notions, on the implications they might have for the patients and the people around them. 
By doing so, students are encouraged to develop their Higher Order Thinking Skills (Bloom 1956), essential in the formation of every individual. Indeed, whereas the students who remember and simply understand information might be said to practice the Lower Order Thinking Skills, students who make an effort to understand the reasons why certain things are the way they are, the consequences this entails, the way certain things work, etc., are encouraged not only to learn new information, but also to evaluate and assess it, connect it to previously acquired knowledge, and learn to use it in future situations.

This is the reason why through the kind of approach outlined here, it becomes possible to stimulate the growth of students not only from a purely linguistic perspective but from a more holistic one, pointing to a change in the way we consider specialized translation. Naturally, the formation of such a professional figure should be conceived as a long term goal of translation degrees and cannot be compressed in the 36-hour courses on which this paper is based. This perspective, however, should inform the syllabus of individual teaching modules and the course catalogue of Courses in Foreign Languages. Indeed, even during short translation courses such as those described in this article, translation teachers can offer some input in this direction and, especially if the course represents the first approach to medical translation on the students' part, build the basic knowledge and competence which learners will be able to improve throughout their following professional career and their lifelong learning experience, which, as well known, is encouraged by the European Union since 2000 (see for instance the Lisbon European Council and its Strategy mandates: Commission of the European Communities 2000; the Lisbon Strategy mandates 2010, renewed as "Education and Training 2020") and UNESCO itself (UNESCO 2014) (see also Aspin 2007, among the many).

From this perspective, the use that teachers can make of television products to arouse students' initial interest in medical domains and rise their awareness both from an interlinguistic and an intercultural perspective appears very stimulating.

\section{Aims, methodology and material}

This paper thus aims at presenting some of the activities carried out during two introductory courses to demonstrate how television series such as House M.D., and situation comedies such as Scrubs can be analysed by students both in the original and dubbed versions and exploited in order to approach medical translation during a course aimed at non-specialists. The students attending the courses were not, in fact, medical students, but undergraduates reading modern 
foreign languages, who initially had a $\mathrm{Cl}$ level of English. The courses were held during the second semester of 2015-2016 and 2016-2017, and extended from February till May for a total of 36 hours of lessons in presentia. The attending students were, in both academic years, approximately 100 , and during the courses they were required to add 114 hours of individual study.

Since students were attending their third year, it was taken for granted that they would be able to use CAT tools, consult other sources of information such as reference, specialized corpora and parallel corpora, and know how to carry out frequency lists and concordances.

Having demonstrated the usefulness of popular products in teaching specialized languages elsewhere (see Canepari 2016; $2017 \&$ forthcoming), this paper investigates the possibility of exploiting these products strictly from a translation point of view, in order to outline a path of research useful in the creation of a medical translation syllabus capable of accounting for the complexity of both specialized translation and the world in which the students, as translators, will be required to perform.

The decision to use audio-visual materials was based on the acknowledgment of the fact that "video aids learners' comprehension of English" (Stempleski 1987) and the idea that this modality could thus be fruitfully adapted to a new context, namely specialized translation. Indeed, the notion of videos as facilitators of the mental process has gained large consensus among language teachers and trainers (see for instance: Stempleski \& Arcario 1992). As Tomalin recognizes, videos can in fact become highly motivational (1991) and, as Stoller maintains, can be used as "effective springboards for other classroom activities" (1993: 3), providing the background information and additional stimuli for subsequent activities.

As this paper suggests, despite its conciseness, the activities were very diversified and involved using various aids (videos, illustrations, charts etc.) in an attempt to motivate students and help them focus on different aspects of the translation process. Thus, on the basis of the videos they were required to watch, students were asked to fill in tables, create diagrams, solve puzzles, perform role-play, find extra-materials etc.

Various neuroscience studies have actually demonstrated that "significant increases in learning can be accomplished through the informed use of visual and verbal multimodal learning" (Fadel 2008: 12). In point of fact, presenting elements in more than one sensory mode (visual, audio, written), and designing activities that involved different skills on the students' part (reading, listening, written/spoken production, translation, corpora consultation etc.) improved their attention, made complex information such as specialized 
language and interaction easier to comprehend and helped them consolidate their knowledge.

In addition, because it can relate to "the specific perceptual and cognitive strengths of different individuals" (Pashler et al. 2008: 109), the multimodal and multimedia (Mayer 2009) approach described here resulted in a very positive learning performance.

Indeed, the responses obtained by the students attending the courses on which the article is based suggest that, if effectively adapted by specialized translation teachers, these products can become useful tools in a learning context. This, as discussed below, is confirmed in spite of the fact that Italian dubbed versions often present a less specialized approach and tend to amplify, substitute and relexicalize some of the specialized terminology used in the original filmic texts in order to originate more popularized goods.

As the paper illustrates, the teacher's creativity in adapting the material at his/her disposal and envisaging possible activities that would be useful in the teaching (and learning) of medical translation becomes essential, and can result in stimulating course work.

\section{The popularization of medical language and its benefits in a learning environment}

Television products which involve intersemiotic (Jakobson 1959) translation and adequate use of the specialized language(s) of medicine, have always had a strong presence in the organization of television schedules and their number has recently increased notably. Indeed, since the 1950s, television has released new medical series on a regular basis (see for instance City Hospital, 1951; The Doctor, 1952; Dr. Kildare, 1961; General Hospital, 1963; $M{ }^{*} A{ }^{*}{ }^{*} H$, 1972; St. Elsewhere, 1982, to name a few), and from the 1990s onwards the number of medical dramas aired on television has increased at an impressive rate. To give just a few examples among the many, we can mention: Chicago Hope, 1994; E.R., 1994-2009; L.A. Doctors, 1998; Crossing Jordan, 2001; Scrubs, 2001; House M.D., 2004; Grey's Anatomy, 2005; Private Practice, 2007; and so on, up to the more recent Chicago Med, 2015 and The Good Doctor, 2017.

As discussed in detail elsewhere (Canepari 2013), in this context, the notion of intersemiotic translation has to be understood in rather broad terms, in so far as, contrary to what happens for instance in the field of literature, where novels are often translated (more or less faithfully) and adapted to films or television series, in the field of specialized languages it is very difficult, if not impossible, to find particular books translated into specific audio-visual goods. In this sense, we could identify the source text which is adapted in 
audio-visual products with a form of language that, with all due caution, might be compared to the archi-writing of Derridean memory (Derrida 1967: 60), namely that form of generalized writing from which, according to Derrida, all the other forms of language (including spoken language) derive. Clearly, this is not the place nor the time to discuss the notion Derrida discussed in his seminal work De la Grammatologie in order to deconstruct the metaphysics of presence he saw inherent in Saussure's distinction between signified and signifier and the privileged status granted to 'speech' (that is logocentrism). This notion, however, might become useful to conceptualize the idea of 'specialized language' as understood here, namely as a language which does not coincide with the particular language used in a specific text, but with a more, almost 'atavic', essence of (specialized) language and text, intertextually composed of different extracts which originally belonged to different works. It is precisely this specialized archi-language, which is referred to, exploited and inserted in written, audio and audio-visual materials and which is translated constantly in order to be adapted to the new media in which it is used.

Hence, from this perspective, the materials and textual types which appear to translate specialized languages - and which can be exploited in a learning environment - are innumerable. Furthermore these (audio-visual) texts are easily retrievable, and often coincide with products which are 'popular' not only in terms of the less specialized use of language they make, but also because they are frequently highly rated by the students themselves, who know and appreciate them outside their academic environment. As a consequence, the inclusion of these products in a syllabus can clearly help the learning process, turning it into a more motivating experience, rendering specialized languages less abstract and, as a consequence, facilitating the comprehension (and subsequent acquisition) of specific notions, structures and terminologies. Indeed, since second language learning is often hindered by affective filters (Dulay $\&$ Burt 1974; see also: Krashen 1981; Arnold 2001), the lowering of these filters by resorting to these series might result in more effective courses. Naturally, the teaching (and learning) of ESP cannot be considered equivalent in toto to the teaching (and learning) of English as a second language. However, by adapting to specialized language in general Tiersma's statement, according to which "[specialized] language and ordinary English are, in a sense, two different languages [...]" (online), and by considering the fact that the activities presented here were directed to Italian students of English, it is indeed possible to identify features that are shared by both domains.

The exploitation of audio-visual materials actually renders the learning environment more natural and more engaging, also from an emotive point of 
view, for both students and teachers. The relevance and importance of these aspects has been repeatedly emphasized since the early studies of Krashen $\&$ Terrel in the late 1970s, and also in recent approaches to second language teaching and learning (see for instance Muñoz 2006, and Balboni 2013 among others). Clearly, this setting is not 'interactive', in that the receiver can only remain outside the filmic narrative as an extra-textual interlocutor who does not share the same context and cannot interact with the other characters that appear on screen. In spite of this, by using this methodology, the students are confronted with the spoken language of the filmic text rather than being simply presented with a printed text and they can observe actual people using specialized language in a "natural" (albeit fictional) environment, and through various types of activities can engage with those languages and project themselves in similar settings. In a way, then, this kind of approach manages to simulate a natural situation, creating a sort of 'authentic (albeit fictional) environment' within the classroom. By reproducing some of the dynamic and transient nature of the spoken word, in fact, this language can be seen as a closer imitation of actual orality, and while losing, since it is used in fictional situations, the reliance on clues other than the linguistic ones in order to decipher the message (Chafe 1982; McCarthy 1998), it can be considered as helpful in the creation of 'close to life' situations, with which students might empathize. As Shrosbree (2008) maintains, in fact, videos provide that environment which is usually absent in a traditional classroom, and can therefore improve the learning process. Clearly, teachers should remember that for students, spoken language is, even in non-fictional situations, often more complex to grasp due to its grammatical intricacy (Halliday 1985; Crystal 1996), its structure (often characterized by false starts, sudden changes in topic and morphosyntactic structures etc.) and, generally speaking, the ephemeral nature of the spoken language itself (in that the spoken language of television does not allow receivers to stop, go back, start again etc., all actions which are on the contrary possible when faced with a written text). However, by encouraging students to rely on the new technologies - which clearly contains these difficulties, further blurring the boundaries between one textual type and the other - these problems can at least partially be overcome: by using DVDs, episodes available on the internet, or videos which teachers can create by extracting scenes from audio-visual products, students can in fact stop and go back to listen again.

Obviously, because of the very nature of these products, many of the features that determine the special (and specialized) status of the various languages which compose the macro-category of English for Specific Purposes, undergo various transformations during the process of intersemiotic translation through 
which they are adapted to the new medium. In these forms of edutainment, in fact, specialized languages are regularly subjected to processes of intralinguistic translation too, since this process of adaptation is based on the assumption of a less specialized interlocutor. As a result, the language viewers are confronted with when watching this kind of television show, often appears much closer to everyday speech and writing than actual, specialized language. Although this aspect must be discussed with students in order to make them aware of the transformations that the specialized language of medicine might undergo when the purpose of the translation product is to entertain. As suggested below, it could be turned into a learning opportunity by becoming the basis of future activities. Furthermore, it actually can represent a positive boost from a psychological perspective as it presents materials students are likely to know already, and that they can therefore perceive as familiar, which limits the overwhelming sense of frustration non-specialist students might feel when faced with specialized language and translation for the first time,

For reasons of space, this article cannot address all the issues that this type of analysis raises, but some of the more relevant aspects in terms of the topic and the aim of this paper will be taken into consideration.

For instance, when approaching television series such as House M.D., it appears evident that some of the specialized terminology and some of the main characteristics of medical language are represented in audio-visual products too. This is why rather recent products were chosen, since the series produced in the twentieth century (even those released during the final decades, such as E.R. or Chicago Hope), were characterized by a more naive use of language and they seldom distinguished themselves for their linguistic accuracy. On the contrary, partly because of the demands for a more democratic sharing of knowledge the audience put forward at different levels, ${ }^{1}$ recent series (including situation comedies), distinguish themselves for their level of precision.

This evolution is also evident in the field of legal pathology and forensics - specific branches of the macro-category we broadly refer to as medicine, and which are regularly included in the medical curriculum (Jentzen 2009: 75). However, contrary to other sub-genres such as infectiology, oncology, pediatrics and so on (which often constitute the focus of individual episodes of the same series), the languages of pathology and forensics are often at the centre of different series altogether. Since their language is a particular sub-genre and

1. Let us think, for instance, of such phenomena as Plain English Campaigns or fansubbing, which originate precisely from the desire of the general public to be more in control of their lives. 
belongs to the category of English for Medical Purposes, it should therefore be addressed, albeit succinctly, in a syllabus devoted to the study of this language and its translation. In this case too, then, the didactic approach outlined here can be adapted to this need, by referring to at least one of the many television series which focus on this specific area of study (for instance Crossing Jordan, 2001-2007; CSI, 2000-in production; or Bones, 2005-in production).

The varying degrees of specialization (or popularization) that can be observed in the products mentioned above, might help bring to the fore and discuss two areas of study. The first point of discussion would be the way in which fictional representations of Medical Language have evolved, becoming increasingly precise and specialized and thereby suggesting important considerations on social and sociological aspects of contemporary society. Secondly, it would be useful to discuss the way in which specialized languages have evolved and are developing, from a chronological perspective. Indeed, it is important that students should be aware of the different approaches to specialized languages in order to understand how the Target Situation Analysis (Munby 1981) and the Learning Centred Approach (Hutchinson, Waters 1987) have come into being. Furthermore, it would be useful for them to see how the approach set out by the inter- and multidisciplinary field of the Medical Humanities can impact the way specialized languages are used, represented, learned and translated.

\section{A brief account of the coursework}

Clearly, in more recent products too, many of the features which characterize the specialized language(s) of medicine are often either condensed or amplified in order to be more easily understood by the mass audience. In spite of this, as mentioned above, current television series actually present, on screen, many of the characteristics which according to various scholars determine specialized languages (see for instance: Gotti 2005). As such, episodes from House M.D., for example, can be effectively exploited to demonstrate how, through affixation and compounding, words are formed in the language of medicine, simultaneously offering good exemplifications of notions such as "transparency", "conciseness", "monoreferentiality", and so on.

At the same time, they can suggest interesting points of discussion in terms of the exceptions which medical language regularly exhibits in relation to these general features. Any episode can thus become the focus of particular teaching units, in order to demonstrate not only the large use of acronyms made in the language of medicine, but also how, in contradiction for example with general features such as monoreferentiality, precision and lack of ambiguity, the same 
acronyms, within the same specialized field of medicine, can mean different things according to the context in which they are used. Similarly, any episode can become a good exemplification of the way the language of medicine creates neologisms, how it relies on words and affixes of Latin and Greek origin, how it uses numbers, abbreviations, impersonal constructions and so on. In addition, because each episode focuses on particular pathologies, symptoms and cures, working with this kind of material enables teachers to introduce different types of medical lexis.

Obviously, during the initial phase of students' education, when they need to appreciate the way medical terminology works, in order to use and translate it, some of the activities, while based on single episodes, might refer to general medical terms, leaving the investigation of more specific sub-genres to a later phase. Thus, after introducing the notion of 'plain English' and the intralinguistic translation strategies it implies, during the courses discussed here, students were initially required to watch some selected scenes and identify the features that contributed to the 'specialization' of the language used on screen.

For instance, they were initially required to analyse a series of extracts such as the following:

FOREMAN: Let's keep him on the broad-spectrum antibiotics. And since he's displaying septic physiology, draw blood for adrenal and thyroid function.

HOUSE: What about the paralysis?

FOREMAN: We're sticking to the pneumonia.

HOUSE: Well, you certainly are, boss, like a wet tongue sticks to dry ice.

FOREMAN: The paralysis has already been diagnosed by Dr. Hamilton. It's A.L.S.

HOUSE: Lou Gehrig's disease. It's a lovely diagnosis. They make movies about it. No tests, no treatment - It's a disease of exclusion.

FOREMAN: Because Hamilton has excluded everything else.

HOUSE: I haven't.

FOREMAN: What else could it be?

CHASE: Guillain-Barré, which would be reversible.

HOUSE: Excellent.

FOREMAN: No. The progression of the paralysis would be symmetric. His wasn't.

CAMERON: Transverse myelitis.

FOREMAN: Hamilton tested for it. Negative. And he was negative for masses and A.V.M... 
CHASE: Antibodies could be attacking the nerves. Multifocal motor neuropathy.

HOUSE: Uncommon, but it fits. It's also treatable. Did Hamilton try putting the guy on I.V. I.G.?

FOREMAN: No, because the M.R.I. showed no...

HOUSE: Well, let's do an M.R.I. of our own.

FOREMAN: Guys, it's my case. A.L.S. fits. It even predicts the pneumonia. The paralysis is progressive.

HOUSE: It's a death sentence.

FOREMAN: That doesn't make it wrong (House M.D., Season 1, Episode 9, "D.N.R.").

Most of the students were able to signal the presence of compound words (antibiotics, neuropathy), words of classical origin (physiology), dense noun groups (multifocal motor neuropathy), acronyms (A.S.L, M.R.I.), eponyms (Lou Gehrig's disease), whereas they were unable to detect and understand other abbreviated forms such as I.V. or I.G. This exercise, however, was a very useful starting point, which enabled students to identify some of the main features of Medical English while positing the basis for other activities. In fact, they were subsequently required to find the meaning of the various specialized terms and acronyms in English and translate them first intralinguistically (thereby giving an explanation in ordinary language), and then interlinguistically, providing a translation into Italian, using both paper/online dictionaries and corpora. After discussing and, when necessary, filling in the data provided by students, the students were asked to complete a table with the various characteristics of the English words and expressions they had noticed beforehand, the features of Medical English that accounted for them, the definition and, when possible, the translation into ordinary English of those words/expressions and, finally, their translation into Italian:

\begin{tabular}{|c|c|l|l|l|}
\hline $\begin{array}{c}\text { Word/ } \\
\text { Expression }\end{array}$ & $\begin{array}{c}\text { Feature(s) } \\
\text { of Medical } \\
\text { English }\end{array}$ & \multicolumn{1}{|c|}{$\begin{array}{c}\text { Meaning/ } \\
\text { Definition }\end{array}$} & $\begin{array}{c}\text { Translation } \\
\text { into Ordinary } \\
\text { English }\end{array}$ & $\begin{array}{c}\text { Translation } \\
\text { into Italian }\end{array}$ \\
\hline Polypectomy & $\begin{array}{l}\text { Compounding; } \\
\text { classical origin }\end{array}$ & $\begin{array}{l}\text { Excision } \\
\text { of a polyp }\end{array}$ & $\begin{array}{l}\text { The removal, } \\
\text { through } \\
\text { surgery, of } \\
\text { growths of } \\
\text { tissue }\end{array}$ & Polipectomia \\
\hline
\end{tabular}

Table 1 
With each assignment, students were asked to add to the same table, in order to create a well-documented chart. Indeed, once the first phase of the work on the first extract was concluded, students were asked to analyse extracts from the situation comedy Scrubs such as the following, adopting the same kind of perspective (thus providing a translation first into plain English and then in Italian of some of the most technical terms), also noticing however the linguistic elements that differentiate the two series, assigning the latter to the sub-genre of comedy:

NURSE: Patient's complaining of anosmia.

J.D.: Anosmia? I always thought it was very funny that losing your sense of smell was called anosmia.

Anosmia, you know, like Schnozmia. Don't you find that very funny?

NURSE: He doesn't. [...]

J.D.: Anosmia isn't a side-effect of IV imipenem.

Plus, Mr. Blair had nasal polypectomies and septoplasty and his loss of smell is caused by manipulation of his sinuses and the infection, so I didn't make a mistake (Scrubs, Season 2, Episode 5).

Students immediately noticed for instance that the specialized term "anosmia" was translated intralinguistically within the episode itself by having the main character stating "I always thought it was very funny that losing your sense of smell was called anosmia", and immediately recognized the pun the young doctor makes ("Schnozmia"), the term "imipenem" (which upon research they were able to identify as an antibiotic). Thanks to their previous analysis, the acronym "IV", for which this time they were immediately able to give the extended version "intravenous", was then recognized as a marker of specialized language due to its affixation and its Latin origin.

Following a discussion of the role played by acronyms in medical language, as witnessed in the previous extracts, one particular episode of Scrubs became truly valuable. In the thirteenth episode of the first season, in fact, Dr. Cox instructs his interns on the meaning of some of the most common acronyms used in medical charts and among doctors:

COX: Now, ladies and germs, I guarantee you that if you get this shorthand down, it has a way of making your day go just a little bit quicker. "C.T.D." of course being "circling down the drain" - your patient is on the way out. "S.O.B." - "Shortness of breath"; and "W.N.L." - "within normal limits". Elvis, you go ahead and feel free to write this down anytime you want before you leave the building, sweetheart. (Scrubs, Season 1, Episode 13, "My Balancing Act"). 
Using extracts such as the above as a starting point, students were then asked to rely on the new technologies and corpora in order to find other acronyms which are frequently used in the language of medicine, providing their extended expressions, giving their explanation in plain English and finding an equivalent in Italian. However, in order to monitor how much they had retained from the courses they attended in the previous years of their University, and understand what they might find more useful and easier to use, they were asked to indicate all the sources they had consulted and the level of difficulty the various entries they found had entailed.

At the same time, their attention was directed to the strategies of intralinguistic translation such as explicitation typical of popular products and some of the strategies of re-lexicalization, which Tannen (1989) and McCarthy \& Carter (1994) described as typical of spoken language. Naturally, teachers have to make sure that the fictionality of these series is emphasized through and through, in so far as what viewers and students are confronted with is not actually spoken, natural language, but a language which was written in order to be recited. However, the spoken mode on which audio-visual products rely is certainly much closer to orality than, for instance, the dialogues in a medical novel such as Oxygen by Cassella (2008) or The Second Opinion by Palmer (2009), to name just the most recent and popular ones, can be. This aspect determines not only the importance of all those elements that characterize spoken communication (namely, body language, gaze behaviour, intonation, pitch, stress, pace etc.), but also, as the analysis of any episode of House M.D. makes patent, the fact that the language used, when compared to the written language of articles and books, is typically characterized by a lower lexical density, by re-lexicalization as introduced above and by a structure which is generally organized on the basis of the turn-taking system which determines the way actual conversations are organized. These aspects clearly appear consistent with the idea of popularization at the very basis of products such as the two television series on which this article focuses, and have a major impact on the register adopted in the conversations recreated on screen too.

For example, metaphors - which notably play an important role in the language of medicine actually used by professionals - are often exploited in the television series too. In actual fact, one of the stimulating aspects of House M.D., which is typical of the situation comedy Scrubs too, is the fact that, within the intradiegetic (Genette 1972) microcosm that the filmic narrative creates, various degrees of specialization are represented. Indeed, we can find situations when specialists from the same field communicate; occasions when one specialist speaks with a specialist from another area (generally House, who 
specializes in infectiology, and Wilson, who is an oncologist); learning environments in which a doctor interacts with his/her trainees, and circumstances when doctors have to confront 'laymen' (generally the patients themselves or their relatives) and therefore have to translate intralinguistically many of the medical notions they refer to.

As a consequence, television shows such as these might be very stimulating for students, precisely because they present situations they can more easily relate to. Although it is true that the courses under consideration are directed to non-specialists, who will never act as trainees in hospitals, the very fact that the characters are often represented as studying, preparing exams, being tested during the rounds and relating to their professors/doctors, clearly creates a form of sympathy and empathy with their situations as represented on screen and can be perceived as an environment they at least partially know. Furthermore, the presence of a didactic environment entails the enactment of strategies on screen that can prove very useful for extradiegetic receivers too, in so far as they can take advantage of the explanations that, within the intradiegetic world of the television show, are directed to the intradiegetic receivers. At the same time, they help students realize that, were they to act as simultaneous interpreters in hospitals, they would have to take into consideration the strategies of 'popularization' they would have to adopt, together with the necessary interlinguistic strategies, in order to facilitate the communication exchanges between doctors and patients.

In this sense, it was very interesting to analyse some of the metaphors created by Dr. House and his colleagues. During this phase of the course, students were thus required to identify the various semantic fields exploited and compare them to the semantic fields characteristic of actual medical language, on the basis of the studies conducted for example by Hudgkin (1985), Gotti (2005) and Fuks (2009). Thus, in the following example, students were able to identify the military metaphor Dr. House resorts to and which plays a fundamental role in actual medical language (among the many, see: Hodgkin 1985; Fuks 2009; Reisfield \& Wilson 2004; Mansfield 2012):

HOUSE: The tumour is Afghanistan, the clot is Buffalo. Does that need more explanation? OK, the tumour is $\mathrm{Al}$ Quaeda. We went in and wiped it out, but it has already sent out a splinter cell - a small team of low level terrorists quietly living in some suburb of Buffalo, waiting to kill us all [...] It was an excellent metaphor. Angio her brain for this clot before it straps on an explosive vest. (House M.D., Season 2, Episode 2, "Autopsy").

Naturally, other issues became the focus of analysis too. First of all, from a linguistic point of view, the word 'angio' was discussed, as an exemplification 
of the tendency to abbreviate words in the attempt to be more concise and the changes of grammatical class to which words are often subjected in English Medical Language in order to originate neologisms, as in this case 'angio' is used as a verb with the meaning of 'to perform an angiography'. Naturally, when students were asked to translate this term, they experienced some difficulties, in so far as in the Italian language of medicine, changes of this kind are more difficult and rare. This led them to suggest a diffused translation such as fare una angio [literally, 'do an angio', where the compound angiografia, direct equivalent of angiography, is abbreviated in Italian too]. In addition, cultural and intercultural issues were discussed, in order to assess the acceptability of the references activated by the metaphor used by House and the highly connotative terms he uses on the basis of the context of situation, the participants in the communicative exchange etc.

In a similar way, students were asked to analyse extracts which exhibited, among others, sports metaphors:

CAMERON: Idiopathic T-call deficiency?

HOUSE: Idiopathic, from the Latin meaning we're idiots 'cause we can't figure out what's causing it. Give him a whole body scan.

CAMERON: You hate whole body scans.

HOUSE: 'Cause they're useless. Could probably scan every one of us and find five different doodads that look like cancer. But, when you're four down, 100 to go, in the snow, you don't call a running play up the middle. Unless you're the Jets. (House M.D., Season 1, Episode 17, "Role Model").

In this case too, the expression "Idiopathic T-call deficiency" was commented upon from a purely linguistic perspective and translated, in order to add the data to the table created at the beginning of the course. A further cultural issue was also discussed, in so far as the reference to the game of baseball might result obscure (and therefore useless) to an Italian receiver. This both in terms of audio-visual translation and in an imaginary scenario in which students were working as translators in an American hospital where Italian patients were treated.

At a later stage, students were asked to find other documents (either spoken or written) which could testify the importance of these metaphors in the language of medicine. Naturally, as before, this type of assignment represented a good testing ground for the students' research and technological abilities, and touched on both English and Italian medical language. The aim was for students to identify the most common metaphors in one language and the other and see whether some semantic fields were absent or present in one 
language but not the other. From the results of the students' investigation, they were able to confirm that quite often the metaphors found in English work in Italian as well simply through equivalence. Thus, in Italian, the military metaphor is equally productive and, in a similar way as English Medical Language refers to 'magic bullets' against cancer, in the target language we find pallottole magiche as a privileged metaphor to indicate the chemotherapic drugs (Montagne 1988: 418; Bellani 1991: 285). However, whereas in the discourse about cancer in English we generally talk about 'rogue cells' (Sontag 1989: 17), thereby expressing a treacherous entity, in Italian we tend to talk about cellule impazzite ('mad cells', Cipolla 2004: 107), thereby shifting the emphasis and the connotative value of the term.

Following this activity, students were asked to translate intralinguistically parts of the text. On this occasion, however, they were required to render in medical English some of the less specialized and semi-technical terminology ordinary people often use into medical English, either on the basis of the episodes from the television series used during the course (where for instance the expression 'banana bag' often substitutes the more technical 'intravenous drip' - see for instance House M.D., Season 1, Episode 10, "Histories"), or by referring to other episodes/series or their own experience. The results were rather interesting for students who for instance identified 'humerus' as a valid equivalent for the ordinary 'upper arm bone'; 'ulna', as the more specialized synonym for 'forearm bone'. Thus, when asked to translate these expressions, they admitted that, on this occasion, Italian has equivalent strategies, contemplating a more ordinary expression for omero [literal rendition of 'humerus'], that translates into braccio (literal translation of 'arm', which is however not qualified as in English in 'upper'), and for ulna, which in ordinary language takes a compound form, resulting in avambraccio.

In order to consolidate students' knowledge, this first phase of the course concluded with some additional activities such as the crossword below. Thanks to such activities, students were able to revise the terms on which the previous lessons focused and consolidate their lexical skills. By being required to find, on the basis of a definition in plain English, the corresponding specialized term which then they had to translate into Italian, this activity also served as a moment of self-assessment which proved, most of the time, highly motivating for students: 


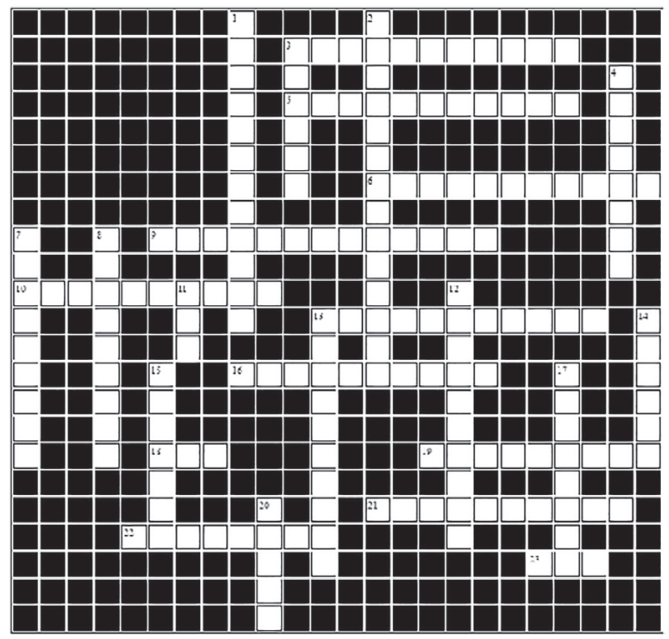

Across

Down

3. Responsible for nerve conduction to and from the brain and the body 1 . Inflammation of the brain

2. Agents that prevents or lessens convulsion

6. Surgical repair of a nerve

9. Drug that prevents clotting of the blood

10. paralysis from the waist down

13. Excision of part of the skull to approach the brain

16. Condition of difficult articulation

18. Brain and spinal cord

19. pain along the course of a nerve

21. Inflammation of the meninges

22. Largest part of the brain

23. Recording of various aspects of sleep

3. Damage to brain caused by cerebrovascular disease

4. Agent that has a calming affect

7. Agent that induces sleep

8. agent that relieves pain

11. Record of the minute electrical impulses of the brain

12. paralysis on one side of the body

13. Incision into the skull to approach the brain

14. Paralysis

15. Fainting

17. Inflammation of the spinal cord

20. Portion of the CNS contained within the cranium

Figure 1. A crossword puzzle (ArmoredPenguin.com)

\section{Audio-visual translation and contrastive analysis}

Having worked on linguistic, intralinguistic, interlinguistic, situational, and cultural issues, taking as a starting point the language presented in the audiovisual products introduced above, the students were then engaged more directly with issues related to the audio-visual translation of the same filmic texts. Obviously, one of the main career options for students attending courses of English Linguistics and Translation is to work as translators. However, while attending their third year usually students have not yet made a clear decision as to the type of translation they want to specialize in (specialized, audiovisual, editorial etc.). As a consequence, the second part of the course aimed at showing how a different kind of translation (in this case audio-visual) might work. 
For this reason, students were asked to work on the same extracts they had examined previously, performing however a contrastive analysis of the original texts and their dubbed versions. Thus, after watching how the same scenes were rendered in Italian, students were required first to investigate whether features such as intonation, turn-taking, hedges etc. were subjected to any change during the translation process.

They were then required to work on the scripts themselves, creating another table in order to report the way the source text was dubbed, the strategy adopted on those situations and, if the translation was different from the one they had suggested during the previous phase, their own option.

\begin{tabular}{|c|l|l|l|}
\hline \multicolumn{1}{|c|}{ Source Text } & \multicolumn{1}{|c|}{ Dubbed version } & \multicolumn{1}{c|}{$\begin{array}{c}\text { Translation } \\
\text { Strategy }\end{array}$} & \multicolumn{1}{c|}{ Students' option } \\
\hline Lou Gehrig's disease & $\begin{array}{l}\text { Sclerosi laterale } \\
\text { amiotrofica }\end{array}$ & Substitution & $\begin{array}{l}\text { Morbo di Lou } \\
\text { Gehrig }\end{array}$ \\
\hline
\end{tabular}

Table 2

For instance, students immediately noticed that from the very first scene analysed there were some omissions in the dubbed version. Thus, the target option for the expression "broad-spectrum antibiotics" - namely "antibiotici a largo spettro" - corresponded to the option suggested by the students themselves, who either on the basis of their life experience or through the searches they carried out during the first phase of the course (in particular concordance searching), could confirm that this was the equivalent in the Italian language of medicine. Yet, the remaining sentence ("And since he's displaying septic physiology, draw blood for adrenal and thyroid function") appeared lacking various elements which, in the source text, added to the 'scientific information' presented within the show. Indeed, no reference to "septic physiology", or "adrenal function" is made, whereas the expression "to draw blood" (which indicates a specific diagnostic test) is rendered with a much vaguer "fare un controllo" (meaning 'to check'). Since most students had translated all the elements of the sentence, they were encouraged to consider the reasons that might have led translators to render the sentence in such a way, and the consequences this choice could have on the target text and its receivers. Naturally, the possibility that the choice of translation procedures such as omission and reduction was determined by the technical constraints that audio-visual translation imposes was taken into consideration. However, the word count of this first turn demonstrated that the Italian text was actually shorter than the English. During a short role-play, students actually timed themselves when 
delivering this first part of the dialogue, and proved that, even without relying on the new advances in technology, which enable to either reduce or increase the speed of the utterance and modify facial and lip movements of actors to synchronize their speed in the target language, a much more complete and faithful translation such as the one they had produced would have been possible. This was further confirmed by the translation found later on in the same extract, when "Guillain-Barré", which in the English version does not collocate with any other word, in the dubbed text is rendered as "Sindrome di Guillain-Barré" (literally Guillain-Barrés disease), thus adding ten characters to the original. Clearly, students agreed on the fact that the omissions noted above, while not hindering the general meaning of the source text and enabling Italian receivers to enjoy the television show, diluted the specialization of the text itself, thereby changing the thematic and figurative isotopies (Greimas 1966) of the original. From a psychological and emotive perspective, then, this was a very important moment for students, not only because they felt quite pleased with themselves, but also because they realized that the level of precision required by specialized translation might well be called for in other types (and much more popular) translations too.

Another aspect that students noticed was the fact that the acronym A.L.S., which in the English version is translated intralinguistically immediately after its first appearance as "Lou Gehrig's disease", in the Italian version is rendered first with the Italian acronym "S.L.A." and, immediately afterwards, as "Sclerosi Laterale Amiotrofica", equivalent and literal translation of "Amyotrophic Lateral Sclerosis".

At this stage, students were already aware of the fact that eponyms are often used in the language of medicine to indicate a specific condition. During the previous part of the course, in fact, this extract was used as the starting point to illustrate how the language of medicine is actually characterized by many exceptions to the very notion of 'lack of ambiguity' which is often cited as typical of specialized languages. In particular, since students had, in their reading list, extracts from Strasser's "Tour de Babel" (1980), and Gotti (2005), they were aware of the fact that the same pathology can be identified by many different terms in English. They were also able to note two important features: first that sometimes not only the same medical condition can be identified by its scientific name and the name of the person who discovered either the disease or the cure, but also that, since various researches from different countries sometimes claim to be the discoverers of the same scientific discovery, the latter is subsequently indicated by different eponyms according to the nation in which it is referred to (see Gotti 2005: 36-37). In this specific case, through 
the search they had carried out earlier in the course, students knew that this medical condition is known, in Italy too, as il morbo di Lou Gehrig (literally 'Lou Gehrig's disease'), after the famous baseball player from the New York Yankees who was diagnosed with this neurological disease in 1939. Thus, when asked which might be the consequences of this translation choice, the students recognized that by simply using the extended version of the acronym, the Italian text seemed to obscure an important characteristic of medical language in both its English and its Italian varieties (see for example Gelmetti 2015).

A similar approach to the translation of acronyms was noticed in the following lines too, where the original 'A.V.M.', rather than being translated into the corresponding Italian acronym (M.A.V.), is immediately rendered explicit in the translation through recourse to the extended formula which, in English, reads 'Arterio-Venous Malformation' and which in Italian becomes Malformazioni arterovenose. Likewise, the two acronyms 'I.V. I.G.' (which by now students had learned stand for 'Intravenous immunoglobulin'), are translated by adopting the same procedures into Immunoglobulina in vena. Finally, the acronym 'M.R.I.' ('Magnetic resonance imaging') was discussed. Indeed, most of the students had previously translated it with the Italian equivalent R.M.I. - namely risonanza magnetica per immagini. Rather than opting for the Italian acronym, however, the dubbed version presents an explicit translation, abbreviating the Italian definition as risonanza (literally, 'resonance'). As a matter of fact, this specific radiology examination is often indicated in Italian by the shorter acronym R.M. and is often referred to simply as risonanza magnetica. In consideration of the intradiegetic situational context and the interlocutors engaged in the communicative act, as well as the popularization typical of the product in which the term is inserted, the latter was actually the option selected by most of the students, who, on the basis of the searches they had carried out, deemed the Italian dubbing too imprecise, as the same word assumes a different meaning in medicine, physics, chemistry etc.

This phase dedicated to the contrastive analysis of the source and target texts, then, resulted very useful at more than one level, in so far as, while giving the students a great deal of self-confidence, confirmed once more that the initial phases of the translation process, devoted to the analysis of the source text and the necessary searches, are actually essential.

On the basis of the various strategies students had identified in the rendition of the dialogues of the television shows, the following stage of the course focused on the specific element of titles and the way they were rendered into Italian. 
After making available to students a chart with various episode titles and their respective translations, they were asked to indicate whether they considered the target titles acceptable or unacceptable and why, encouraging them to find alternative solutions if needed.

For example, the title of the third episode of the first season, which in the original reads "Occam's Razor", was translated into Italian as "Una sfida per House" ("A challenge for House"). Although students acknowledged the fact that the choice of this substitution does not actually affect the general meaning of the episode, they also recognized that the omission of this reference impinges on the register of the episode itself, omitting the introduction of a scientific notion into the title which clearly works as a cohesive device within the filmic narrative in its entirety. Yet, the principle to which "Occam's Razor" refers - namely the idea that among competing hypotheses that predict equally well, the one with the fewest assumptions should be selected because, even though more complicated solutions may ultimately prove to provide more accurate diagnoses, the fewer assumptions are made, the better - is very well known all over the world. In particular, since the phrase has appeared as the title of songs (see for instance: "Occam's Razor", Porcupine Tree 2009) and in other products of mass production (comics, sitcoms etc.), the students were quite familiar with it, and for the most part knew that in Italian the standard translation is, literally, Il rasoio di Occam, the alternative which they proposed as a more acceptable translation.

Clearly, the substitution procedure performed in the translation of the title of the third episode of the first season - which in the original reads "Humpty Dumpty" and is rendered in Italian as Sensi di colpa ('Guilt') - was deemed by students slightly more justified from a cultural point of view. In point of fact, the original title refers to the character of a very famous English nursery rhyme, which however might not be so well known in Italy, in spite of the fact that it was the protagonist of the animated film Puss in Boots (2011). For this reason, some of the students opted for the reinstatement of the original title, justifying their choice also by referring to the fact that very often when first names are present in a title, the name is left unchanged and the zero-translation strategy is selected.

Similarly, the translation of the title of the episode commented upon above (House M.D., Season 1, Episode 9), namely "D.N.R.", which was rendered as Rianimazione vietata ("It is forbidden to reanimate"), raised more than one issue. Indeed, on this occasion, the acronym, which in English means 'Do Not Resuscitate/Reanimate', is in fact explicitated and translated intralinguistically, so that the Italian title does not present a short acronym but a much 
longer expression, an aspect which, as the students themselves recognized, loses in effectiveness and halves the impact of the original title. In addition, the expression that was selected among the various possible, does not actually correspond to the one normally used in Italian medical language. As students acknowledged, the exact same acronym does in fact exist in Italy too, where it stands for Da non rianimare (D.N.R.). As a consequence, by adopting this formula, the Italian text would not even have needed the application of the usual procedure of re-ordering which, as the work on these extracts has proven, is regularly adopted. More importantly, it would have maintained the same level of specialization of the source text, referring from the very beginning to actual medical language. Consequently, the way this title was translated appeared rather inaccurate to students, precisely because it seemed to ignore the genre of the original to which the translated text should equally belong.

A rather analogous, albeit perhaps even more relevant example, corresponds to the title of the whole series itself, which the students had not actually considered before. Indeed, the way the acronym 'M.D.' present in the title of the series, is rendered in the Italian version of the television show, represents another example of how translation often disregards the implications of the specialized language used in the original text. In point of fact, the original 'M.D.' means Medicinae Doctor in Latin, thereby pointing to the influence that Latin (and classical languages in general), have on the language of medicine. However, in Italian, the acronym remains unchanged but is subjected to a change of meaning, finally indicating Medical Division. The English expression Italian viewers are confronted with, however, can refer to any ward of a hospital, thus giving no indication of the ward in which House and his team work, namely infectiology.

Certainly, the rendition of acronyms poses various kinds of problems to translators. For instance, as far as the extract from Scrubs analysed above is concerned, it is worth noting that the first acronym mentioned by Dr. Cox - namely 'C.T.D.' ('Circling the drain', which is occasionally substituted, in English, by the acronym 'F.T.D.', meaning 'Fixing to die') (see: Segen 2011), is not actually translated but substituted by the acronym D.N.R. which, as students had learned above, means $D a$ non rianimare. Thus, the original acronym, which represents an expression typical of the informal and colloquial register doctors might adopt, for reasons of conciseness, when compiling the medical records of the patients or communicating intraspecialistically with other doctors or nurses, is translated by resorting to an acronym which expresses not only a different level of register, but also an altogether different meaning. As students immediately recognized, in fact, whereas in the first case the patient is dying 
despite the efforts made by the medical staff, in the second either the patient or his/her family has expressed the wish to avoid what is usually referred to as futile medical care. Despite this difference, the students approved the strategy of compensation adopted here, in so far as it introduced a more scientific language in the Italian version of the show.

Different is the case with 'S.O.B.' ('Shortness of Breath'), the acronym that students initially translated as B.P.C.O. The latter stands for the condition known in Italian as Broncopneumopatia Cronica Ostruttiva, which indicates one of the causes for the shortness of breath indicated by the English acronym, thereby remaining within the same semantic field. In spite of this, within the show, the English acronym is translated according to a procedure of substitution. In the Italian filmic text, it is in fact replaced with G.D.S., meaning Gastro-duodenoscopia, a term normally abbreviated in gastroscopia, which refers, literally to a 'gastroscopy'. On this occasion too, then, the students were rather surprised to see how the dubbed version, while maintaining the formal recourse to an acronym (an aspect which certainly helps assigning this product to the medical field, and allows to recognize the language utilized within the episode as belonging to the macro-category of English for Medical Purposes), introduces completely different elements: whereas in the original text Dr. Cox refers to a symptom, in Italian he talks about a specific diagnostic test. Not only this, but the two versions refer to completely different parts of the human body, which students were easily able to confirm by retrieving different types of informative material, from written texts (UK NHS website), to videos (YouTube) and illustrations (online).

On the contrary, the acronym 'W.N.L.' ('Within normal limits', is rendered in Italian with the corresponding N.L.N., meaning Nei limiti della norma. On other occasions too, as noted by students, the interlinguistic translation is respectful of the expressions and the terminology typical of the Italian language of medicine, so that, for instance, 'Whipple's triad' is rendered, through a faithful translation, as La triade di Whipple. Likewise, 'jaw claudication', which offered a good opportunity to tackle once more the importance of etymology and the history of language, was rendered faithfully in the target language. As students appreciated by consulting the Online Etymology Dictionary, the second term derives from the Middle French $\left(13^{\text {th }}\right.$ century) claudication or directly from the Latin form claudicationem, the accusative form of the feminine noun which actually appears in the Italian dubbing in the nominative form claudicatio. From this, the Italian claudicatio della mandibola we find in the target text. Naturally, the term testifies to the classical origin of both English and Italian medical language, an aspect confirmed by many other words and expressions 
retrievable in the series, where the same procedures of reordering and diffusion are applied (see for instance 'Temporal arteritis', which is translated literally as arterite temporale. However, students were able to identify that, in the translation of 'ataxia dysarthria' for instance, the approach was much more literal and word-for-word, thus resulting in atassia disartria.

Access to the Online Etymology Dictionary, stimulated students, who were then encouraged to investigate the origins of some of the specialized terms encountered so far, and analyse their various component parts. Thus, 'biopsy' was identified as a compound form from the Greek bi-, combining a form of bios, that is to say 'life', and opsis, meaning 'sight', which justified the fact that it was rendered with the direct equivalent which, being equally of Greek origin, results in biopsia. This approach became particularly useful in the interpretation and rendition of a brief monologue Elliot has in front of the new interns who have recently arrived at the hospital of the Sacred Heart where the series is set, during which she describes the mnemonic trick she has invented for herself in order to remember the bones in the hand.

\begin{tabular}{|l|l|}
\hline \multicolumn{1}{|c|}{ Source Text } & \multicolumn{1}{c|}{ Target Text } \\
\hline ELLIOT: & ELLIOT: \\
Scaphoid, lunate, & Scafoide, cuneiforme, \\
triquetrum, pisiform, & pisiforme, semilunare, \\
trapezium, trapezoid, & trapezio, capitato, \\
capitate, hamate. & uncinato. \\
[S.L.T.P.T.T.C.H.] & [C.P.S.T.C.U.] \\
Some Lovers Try Positions That & Sostenere Certe Posizioni Sessuali \\
They Can't Handle. & Traumatizza Certi Uomini. \\
\hline
\end{tabular}

Table 3

At first sight, students expressed a positive assessment of the translation offered by the television show, which seemed quite accurate in terms of register, genre and the specialization of the language used. They noted that some of the translations of the proximal (semi-lunare for 'lunate') and distal raw (cuneiforme for 'triquetrum') appeared quite distant from the original, but after consulting the Italian etymological dictionary (online), they realized that, if this is so, it is because of the addition of a prefix in the first case and a different etymology in the second. Nevertheless, further research confirmed that both terms belong to the Italian language of medicine, and therefore represent effective equivalent in terms of translation. Yet, the translation of 'triquetrum' with cuneiforme (literally 'cuneiform'), raised some issues as students themselves discovered that in Italian the term identifies three bones of the foot and therefore seemed 
out of context both verbally (in that all the other bones mentioned by Eliot refer to the hand) and visually (since the character indicates one by one the location of these bones in her hand as she names them).

During this part of the course the image below was presented to students in order to help them visualize the bones Elliot is referring to in the scene described supra. Indeed, the importance of making referents concrete, in order to help students relate to them more easily has since long been recognized (among others: Mannan 2005). Furthermore, the essential role that images can have in a learning environment has been largely discussed (among others: Clark, Lyons 2004). Indeed, as Mayer suggests, illustrations - especially when they visualize and further explain what is initially presented in a different modality - can heighten students' curiosity and their interest, helping them build useful mental models (Mayer 1989), and focussing their attention on the relevant information. Because of this, during the course a brief activity on the basis of figure 2, which presented the same information communicated in the scene reported above was devised. Students were in fact required to complete the image by integrating the Italian translation of the various terms not according to the translations provided in the situation comedy but relying on their own research work:

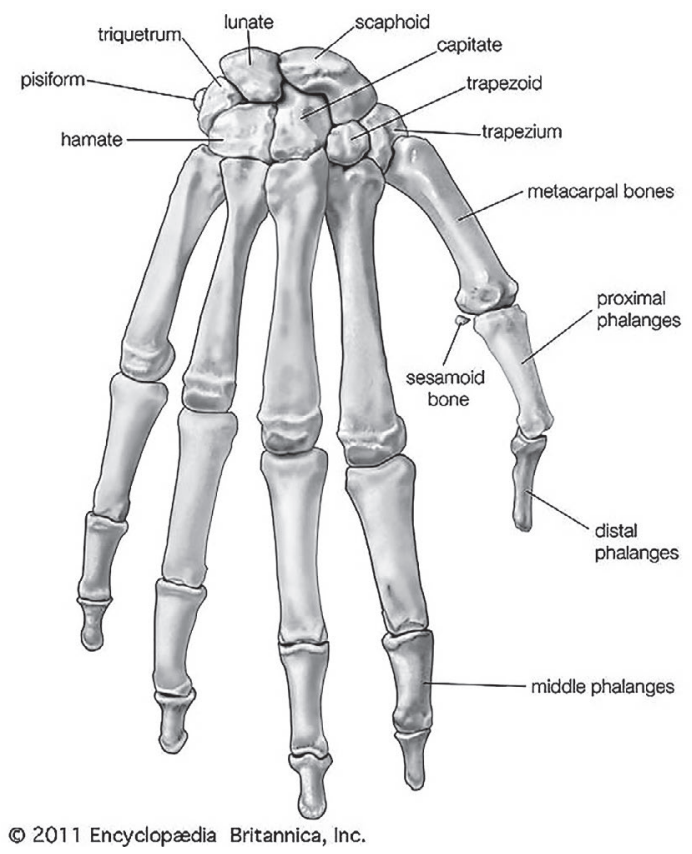

Figure 2. Hand anatomy (Encyclopaedia Britannica 2011) 
This actually proved very useful, since it further encouraged them to acquire materials and do research autonomously - both important aspects from the perspective of critical thinking (Fisher \& Scriven 1997) and, naturally, essential in the formation of translators. Not only this. In fact, it was precisely this work of research that enabled the non-specialist students of the courses to identify, in the Italian audio-visual translation, the presence of a term belonging to the wrong semantic field (the bones of the foot rather than the bones of the hand).

It therefore appears evident that an amusing scene too such as the above can represent a good starting point to introduce some basic vocabulary. Moreover, if supported by activities such as those based on figure 2, it could render the impact of specialized translation less intimidating and more motivating, thereby resulting in better language acquisition. Indeed, if students feel at ease, they experience lower anxiety and therefore learn and perform better (see for example Peirce 1995; Arnold 2001). In addition, mistakes could also be usefully exploited and through activities such as 'Can you find the mistake?' or 'Find the odd one out', might represent a challenge for students, who can be thus further stimulated.

This is particularly true when dealing with products such as Scrubs, where the humoristic tones of the filmic text turn it into a very valuable tool, through which students can practice their translation skills at more than one level.

As illustrated above, in fact, many scenes of the show can be used to focus not only on particular lexical items (their formation, their etymology, their equivalents etc.), but also on interlinguistic translation and the type of register and intralinguistic strategies that could be adopted when acting in different situational contexts, defined by participants who differ from the point of view of status, education, age etc. For instance, the dialogues between doctors and patients we see represented on screen might well be studied from this particular perspective, in order to see whether the tenor (Halliday 1978) that the television series assigns to these communicative exchanges, actually reproduces the tenor real life doctors adopt with their patients, as studied for example by Wodak (1997), Roberts (2000), Adegbite \& Odebunmi (2006), Li, H.Z. et al. (2007), Belder et al. (2013), among others. During the courses this article is based on, this issue became very relevant in the discussion of House M.D., where the protagonist often appears extremely abrasive when relating to both his colleagues and his patients. In Scrubs, on the contrary, the humour to which the characters resort in the intradiegetic world of the television series - is actually very sharp and sometimes rather offensive, especially between colleagues - creates a different kind of relationship between doctors and patients. Even though the patients do not always find the doctors' jokes 
funny (see for instance J.D.'s pun 'Schnozmia' above), the efforts made by the young doctor to put the patient at ease will probably be perceived as amusing by the extradiegetic receivers, who therefore are bound to be more prone to absorb some of the aspects presented in the show.

Furthermore, these topics were useful to encourage students reflect upon the different approaches typical of the various 'typologies' of doctors represented on screen, noticing differences in register, intonation patterns, gaze behaviours, body language, and so on.

\section{Conclusions}

As suggested above, the multimodal and multimedia approach outlined here therefore appears consistent with the different approach to medicine propounded by Medical Humanities, in so far as it focuses on both formal issues connected to the specialization of the language of medicine and issues more closely related to the interaction between the senders and the receivers of the message.

Indeed, as David Crystal (2012) suggested, albeit referring to legal language, specialized language should be 'translated' in order to suit the receivers' needs.

The attention to the receiver of the translated text and the recourse to strategies able to obtain not only formal accuracy but actual communication, thus identify a different kind of professional figure within the field of specialized translation.

Naturally, the discussion developed in this paper is, for reasons of space, limited. However, the path outlined here represents an ongoing project which should result not only in further research but a fruitful topic for seminars, masterclasses and translation schools. I thus hope this work has suggested at least some of the activities that proved particularly useful in fostering language awareness and critical reflection.

As suggested above, students' feedback to the general organization of the courses and the activities proposed were actually very positive and resulted in various projects they developed either for their end of course examination or for their final dissertations. In addition, quite a few students became very interested in medical translation and enrolled in specific courses during the postgraduate phase of their academic career. 


\section{References}

ADEGBITE, Wale \& Akin Odebunmi. (2006) "Discourse tact in doctor-patient interactions in English: An analysis of diagnosis in medical communication in Nigeria." Nordic Journal of African Studies 15:4, pp. 499-519.

ARnOLD, Jane. (2001) Affect in Language Learning. Cambridge: Cambridge University Press.

Aspin, David. (2007) Philosophical Perspectives on Lifelong Learning. New York: Springer.

BALBONi, Paolo. (2013) "Il ruolo delle emozioni di studente e insegnante nel processo di apprendimento e insegnamento linguistico." Educazione Linguistica - Language Education 2:1, pp. 7-30.

BELDER, Zara de. (2013) "Power and discourse: comparing the power of doctor talk in two contrasting interactive encounters." Innervate 5, pp. 106-121.

Bellani, Marco. (1991) Psicologia Medica. Roma: Armando.

Bleakley, Alan. (2015) Medical Humanities and Medical Education: How the Medical Humanities can Shape Better Doctors. New York: Routledge.

Bloom, Benjamin. (1956) Taxonomy of Educational Objectives - The Classification of Educational Goals. London \& New York: Longman.

BRAKE, Terence; Danielle Walker \& Thomas WALKER. (1995) Doing Business Internationally: The Guide to Cross-cultural Success. New York: Irwin Professional Publishers.

CANEPARI, Michela. (2013) Viaggio intersemiotico vol. 1 - Prospettive e teorie. Roma: Nuova Cultura.

CANEPARI, Michela. (2017) "The resourcefulness of audio-visual material in designing an EMP syllabus." In: Pop, Anişoara \& Adrian Năznean (eds.) 2017. Updates in Medical English: Studies in Applied Linguistics and ME Methodology. Tirgu Mureş: Editura University Press Tirgu Mureş, pp. 31-52.

CANEPARI, Michela. (forthcoming) Viaggio intersemiotico vol. 2 - Popolarizzazione televisiva. Roma: Nuova Cultura.

Cassella, Carol. (2008) Oxygen. New York: Simon and Schuster.

CHAFE, Wallace. (1982) "Integration and involvement in speaking, writing and oral literature.” In: Tannen, Deborah (ed.) 1982. Spoken and Written Language: Exploring Orality and Literacy. Norwood (New Jersey): Ablex.

Cipolla, Costantino (ed.) (2004) Manuale di sociologia della salute. Milano: Franco Angeli.

Clark, Ruth \& Chopeta Lyons. (2011 [2004]) Graphics for Learning: Proven Guidelines for Planning, Designing, and Evaluating Visuals in Training Materials. San Francisco: Pfeiffer.

CRYSTAL, David. (1996) Rediscover Grammar. London: Longman. 
CRYSTAL, David. (2012) "The state of the language." Electronic version: <www. idea.gov.uk>

DERRIDA, Jacques. (1967) De la Grammatologie. Paris: Minuit.

DulaY, Heidi \& Marin Burt. (1974) "Natural sequences in child second language acquisition." Language Learning 24, pp. 37-53.

FADEL, Charles. (2008) Multimodal Learning Through Media: What the Research Says. San Jose (CA): Cisco Systems.

FISHER, Alec \& Michael Scriven. (1997) Critical Thinking: Its Definition and Assessment. East Anglia: Center for Research in Critical Thinking.

Foucault, Michel. (1961) Historie de la folie à l'âge classique. Paris: Plon.

FouCAult, Michel. (1963) Naissance de la clinique. Une archéologie du regard medical. Paris: Plon.

FUKS, Abraham. (2009) "The military metaphors of modern medicine." Paper presented at the conference Making Sense of Health, Illness, and Disease, Oxford University, July 03-05, 2009. Electronic version: <http://www.inter-disciplinary. net/wpcontent/uploads /2009/06/hid_fuks.pdf>

GELMETTI, Carlo (ed.) (2015) Storia della dermatologia e della venerealogia in Italia. New York: Springer.

GenetTe, Gérard. (1972) Figures III. Paris: Du Seuil.

GotTI, Maurizio. (2005) Investigating Specialized Discourse. Bern et al.: Peter Lang.

GreIMAS, Algirdas. (1966) Sémantique structurale: recherche de méthode. Paris: Larousse.

HaLl, Edward. (1959) The Silent Language. New York: Doubleday, 1984.

HALLIDAY, Michael. (1978) Language as Social Semiotic: The Social Interpretation of Language Meaning. London: Edward Arnold.

HalLIDAY, Michael. (1985) Spoken and Written Language. Deakin: Deakin University Press.

HodGKIN, Paul. (1985) "Medicine is War - and Other Medical Metaphors." British Medical Journal - Clinical Research 291, pp. 1820-1821.

Hull, Melodie. (2016) "Medical language proficiency: A discussion of interprofessional language competencies and potential for patient risk." International Journal of Nursing Studies 54, pp. 158-172.

Hutchinson, Tom \& Alan Waters. (1987) English for Specific Purposes. Cambridge: Cambridge University Press.

JAKOBSON, Roman. (1959) "On Linguistic Aspects of Translation." In: Venuti, Lawrence (ed.) 2000. The Translation Studies Reader. London and New York: Routledge.

JENTZEN, Jeffrey. (2009) Death Investigation in America: Coroners, Medical Examiners and the Pursuit of medical Certainty. Cambridge (Ma) \& London: Harvard University Press. 
KraSHEn, Stephen. (1981) Second Language Acquisition and Second Language Learning. Oxford: Pergamon.

KRASHEN, Stephen \& Tracey Terrell. (1995) The Natural Approach: Language Acquisition in the Classroom. New Jersey: Prentice Hall.

LI, Han Z.; Naghmeh G. Desroches; Young-Ok Yum; Corinne Koehn \& George Deagle. (2007) "Asymmetrical talk between physicians and patients: A quantitative discourse analysis." Canadian Journal of Communication 32, pp. 417-433.

Malone, Joseph. (1988) The Science of Linguistics in the Art of Translation. Albany: State University of New York Press.

Mannan, Bagulia. (2005) Modern Education Audiovisual Aids. New Delhi: Anmol.

MANSFIELD, Gillian. (2012) "Metaphorical medicine: the communicative functions of the pervasive medical metaphor - from everyday life to scholarly journal". La Torre di Babele - Patologia e terapia tra scienza e letteratura 8, pp. 339-358.

MAYER, Richard. (1989) "Systematic thinking fostered by illustrations in scientific text." Journal of Educational Psychology 81, pp. 240-246.

MAYER, Richard. (2001) Multimedia Learning. Cambridge (N.Y.) et al.: Cambridge University Press, 2009.

McCARTHY, Michael. (1998) Spoken Language and Applied Linguistics. Cambridge: Cambridge University Press.

MCCARTHY, Michael \& Ronald Carter. (1994) Language as Discourse - Perspectives for Language Teaching. London: Longman.

MontAGne, Michael. (1988) "The metaphorical nature of drugs and drug taking." Social Science and Medicine 26:4, pp. 417-424.

Munby, John. (1981) Communicative Syllabus Design - A Sociolinguistic Model for Designing the Content of Purpose-Specific Language Programmes. Cambridge: Cambridge University Press.

Muñoz, Carmen (ed.) (2006) Age and the Rate of Foreign Language Learning. Bristol: Multilingual Matters.

MureşAn, Oana; Letiţia Goia; Monica Marta \& Ovidiu Ursa. (2016) "Controversial topics in the EMP class." In: Pop, Anişoara \& Adrian Năznean (eds) 2016. Trends in Medical Language Teaching and Learning. Tirgu Mureş: Editura University Press Tirgu Mureş, pp. 169-172.

Newmark, Peter. (1988) A Textbook of Translation. Hemel Hempstead: Prentice Hall.

Palmer, Michael. (2009) The Second Opinion. New York: St. Martin's Press.

PASHLER, Harold; Mark McDaniel; Doug Rohrer \& Robert Bjork. (2008) "Learning styles: concepts and evidence." Psychological Science in the Public Interest 9:3, pp. 105-119.

PeIRCE, Bonny. (1995) "Social Identity, Investment, and Language Learning." TESOL Quarterly 29:1, pp. 9-31. 
REISFIELD, Gary \& George Wilson. (2004) "Use of Metaphor in the Discourse on Cancer." Journal of Clinical Oncology 22:19, pp. 4024-4027.

ROBERTS, Felicia. (2000) "The interactional construction of asymmetry: The medical agenda as a resource for delaying response to patient questions." The Sociological Quarterly 41:1, pp.151-170.

SANCHÉZ-REYES, Sonsoles. (2011) "Separating the wood from the trees: Methodologically speaking in ESP instruction today." In: Pérez-Llantada, Carmen \& Mida Watson (eds) 2011. Specialised Languages in the Global Village: A Multi-Perspective Approach. Newcastle-upon-Tyne: Cambridge Schilars Publishing, pp. 217-238.

SEGEN, Joseph. (2011) The Doctor's Dictionary: A medical Dictionary Written by a Doctor for Doctors. Pennsauken (New Jersey): BookBaby.

SHROSBREE, Mark. (2008) "Digital Video in the Language Classroom." JALT CALL Journal 4:1, pp. 75-84

SontaG, Susan. (1989) Aids and its Metaphors. London: Penguin, 1990.

STEMPLESKI, Susam. (1987) "Short takes: Using authentic video in the English class." Paper presented at the 21st Annual Meeting of the International Association of Teachers of English as a Foreign Language. Westende: Iatefl.

STEMPLESKI, Susan \& Paul Arcano (eds.) (1992) Video in Second Language Teaching: Using, Selection and Producing Video for the Classroom. Alexandria (Virginia): TESOL.

STOLLER, Fredricka. (1992) "Using Video in Theme-based curricula." In: Stempleski, Susan \& Paul Arcano (eds.) 1992. Video in Second Language Teaching: Using, Selection and Producing Video for the Classroom. Alexandria (Virginia): TESOL. TANnEn, Deborah. (1989) Talking Voices. Cambridge: Cambridge University Press.

The Commission of the European Communities. (2000) The Lisbon European Council: An Agenda for Economic and social Renewal in Europe. Brussels: Directorate General Education and Culture.

The United Nations Educational, Scientific and Cultural Organization. (2014) UNESCO Education Strategy. Paris: UNESCO.

Tiersma, Peter. (NDA) "The Plain English Movement." Electronic version: < http:// $<$ grammar.ucsd.edu/courses/lign105/student-court-cases/plain\%20english. $\mathrm{pdf}>$

WODAK, Ruth. (1997) "Critical discourse analysis and the study of doctor-patient interaction." In: Gunnarsson, Britt-Louise; Per Linell \& Bengt Nordberg (eds.) 1997. The Construction of Professional Discourse. London: Longman, pp. 173-200. 


\section{Filmography}

Bones (2005 - in production), Hart Hanson (creat.), U.S.A.: Fox.

Chicago Hope (1994 - 2000), David Kelley (creat.), U.S.A.: 20 ${ }^{\text {th }}$ Century Fox.

Chicago Med (2015 - in production), Michael Brandt, Derek Haas, Matt Olmstead (creats), U.S.A.: NBC.

City Hospital (1951 - 1953), U.S.A.: ABC (1951-1952), CBS (1952-1953).

Crossing Jordan (2001 - 2007), U.S.A.: NBC.

C.S.I.: Crime Scene Investigation (2000 - in production), Anthony E. Zuiker and Ann Donahue (creats), U.S.A.: CBS.

Dr. Kildare (1961-1966), Max Brand (creat.), U.S.A.: NBC.

E.R. (1994 - 2009), Michael Crichton (creat.), U.S.A.: Warner Bros.

General Hospital (1963 - in production), Doris Hursely and Frank Hursely (creats), U.S.A.: ABC.

Grey's Anatomy (2005 - in production), Shonda Rhimes (creat.), U.S.A.: ABC.

House M.D. (2004 - 2012), David Shore (creat.), U.S.A.: Fox.

L.A. Doctors (1998 - 1999), John L. Hanckock (creat.), U.S.A.: CBS.

$M * A * S{ }^{*} H(1972-1983)$, Larry Gelbart (creat.), U.S.A.: $20^{\text {th }}$ Century Fox.

Private Practice (2007 - 2013), Shonda Rhymes (creat.), U.S.A.: ABC.

Puss in Boots (2011), Chris Miller (dir.), U.S.A.: DreamWorks Animation.

Quincy M.E. (1976 - 1983), Glen A. Larson and Lou Shaw (creats), U.S.A.: NBC. Scrubs (2001 - 2010), Bill Lawrence (creat.), U.S.A: ABC.

St. Elsewhere (1982 - 1988), Joshua Brand, John Flasey and John Masius (creats), U.S.A.: $20^{\text {th }}$ Century Fox.

The Doctor (1952 - 1953), Ros Serling (creat.), U.S.A.: NBC.

The Good Doctor (2017 - in production), David Shore (creat.), U.S.A.: ABC.

\section{Songs}

Porcupine Tree: “Occam's Razor” in: The Incident, Roadrunner Records, New York, 2009.

\section{Websites}

"Crosswords puzzles." Electronic version: <http://www.armoredpenguin.com/ crossword/Data/best/health/med.students.01.html>

"Etymology Dictionary." Available at: <https://OnlineEtymologyDictionary\#/ media/File:Etymonline.png>

"Gastroscopy": The NHS Guide to Gastroscopy." Electronic version: <https://www. nhs.uk/conditions/gastroscopy/>

"Gastroscopy procedure" (video). Electronic version: <https://www.youtube.com/ watch?v=4vDgh3MuLgo> 
"Gastroscopy vs Endoscopy." Electronic version: <http://www.differencein.com/ comparison-of-endoscopy-and-gastroscopy/>

"Hand anatomy." (image) Encyclopaedia Britannica (2011). Electronic version: $<$ https://www.britannica.com/science/hand-anatomy>

"Vocabolario etimologico della lingua italiana." Electronic version: <https:// www. etimo.it/>

\section{BIONOTE}

Michela Canepari is Associate Professor of English Linguistics and Translation at the University of Parma (Italy). After her degree in Foreign Modern Languages and Literatures at the University of Pavia (Italy), she obtained a Master in Critical Theory and a PhD in English Literature from the University of Sussex (United Kingdom). Her major research interests cover postcolonial, cultural, interlinguistic and intersemiotic translation, various branches of linguistics (Discourse Analysis, Critical Linguistics, Sociolinguistics, English for Specific Purposes etc.). Her publications include the books Word-Worlds (2002), Old-Myths-Modern Empires (2005), An Introduction to Discourse Analysis and Translation Studies (2011), English and Postcolonial Translation (2013), Viaggio intersemiotico nel linguaggio della scienza (2013), Linguistica, lingua e traduzione (2016), Working with Linguistics (2017). She is also the author of many articles and contributions on interlinguistic and intersemiotic translation, the popularization of specialized languages, new methodologies in teaching English as a second language.

Dopo la laurea in Lingue e Letterature Straniere Moderne presso l'Università di Pavia (Italia), MiChela CANEPARI ha conseguito un Master in Teoria Critica e un Dotorato di ricerca presso l'Università del Sussex (Regno Unito). Ora lavora come Professore Associato di Lingua e Traduzione Inglese presso l'Università di Parma (Italia) I suoi principali interessi di ricerca spaziano dalla traduzione (interlinguistica, intersemiotica, culturale e postcoloniale) alla discourse analysis, la linguistica critica, la sociolinguistica, i linguaggi specialistici ecc. Fra le sue pubblicazioni, si ricordano i volumi Word-Worlds (2002), Old-Myths-Modern Empires (2005), An Introduction to Discourse Analysis and Translation Studies (2011), Viaggio intersemiotico nel linguaggio della scienza (2013), Linguistica, lingua e traduzione (2016), Working with Linguistics (2017). E anche autrice di numerosi articoli e contributi sulla traduzione interlinguistica e intersemiotica, la popolarizzazione dei linguaggi specialistici, le nuove metodologie nell'insegnamento dell'inglese come lingua seconda ecc. 